\title{
Biodiesel Glycerides from the Soybean Ethylic Route Incomplete Conversion on the Diesel Engines Combustion Process
}

\author{
Renato Cataluña, ${ }^{*}, a$ Zeban Shah, ${ }^{a}$ Leidimara Pelisson, ${ }^{a}$ Nattan R. Caetano, ${ }^{c}$ \\ Rosângela da Silva ${ }^{b}$ and Carla M. N. Azevedo ${ }^{b}$
}

${ }^{a}$ Universidade Federal do Rio Grande do Sul, Av. Bento Gonçalves 9500, 91501-970 Porto Alegre-RS, Brazil

${ }^{b}$ Pontifícia Universidade Católica do Rio Grande do Sul, Av. Ipiranga 6681, 90619-900 Porto Alegre-RS, Brazil

'Universidade Federal de Santa Maria, 97105-900 Santa Maria-RS, Brazil

\begin{abstract}
An evaluation was made to determine the effect of the glycerides presence resulting from the incomplete conversion of soybean biodiesel produced via alkaline catalysis and ethylic route on engine performance, and emissions in formulations containing 10 and $20 \%(\mathrm{~m} / \mathrm{m})$ of biodiesel used as additives in base diesel with low sulfur content and cetane ratings of 45 and 50. By way of comparison, similar formulations were used with soybean biodiesel methyl route with low concentration of glycerides. Tests on a diesel cycle engine with a mechanical fuel injection system indicated that the presence of glycerides decreases the volatility of biodiesel and increase the cetane number of fuels. The higher the cetane number, the higher the particulate matter emissions and the lower the unburned hydrocarbon emissions. Formulations with cetane number 50 showed higher emissions of particulate matter. The presence of glycerides in biodiesel reduces the fuel's vapor pressure, thereby increasing the cetane number and emissions of particulate matter and lower emissions of unburned hydrocarbons. The specific consumption of fuels formulated with biodiesel increases due to its lower enthalpy of combustion and to the presence of glycerides in fuels formulated with soybean biodiesel produced via the ethanol route.
\end{abstract}

Keywords: soybean biodiesel, specific fuel consumption, emissions

\section{Introduction}

The main biofuel used in diesel fuel formulations is biodiesel, a derivative of mono-alkyl esters of long chain fatty acids. Biodiesel is usually obtained through a transesterification reaction of vegetable oils, in which a triglyceride reacts with a short-chain alcohol such as methyl alcohol, ethyl alcohol or isopropanol by means of acid, base or enzyme catalysis from different vegetable oils, waste cooking oils and animal fats. ${ }^{1-7}$ In some cases, formulations with biodiesel increase the formation of deposits in the engine, causing injectors to deteriorate and piston rings to become clogged. It is known that most diesel cycle engines are designed to run on mineral oil diesel and not on biodiesel or blends of biodiesel and mineral diesel. ${ }^{8-10}$ In view of this fact, efforts have focused on improving the characteristics of the engine that influence the quality of

*e-mail: rcv@ufrgs.br combustion. ${ }^{11}$ Due to the properties of biodiesel, the agents most frequently employed in the transesterification process are methyl and ethyl alcohols. ${ }^{2-12}$ Brazil today is the world's largest producer of sugarcane ethanol, which is the fuel alcohol most widely used in this country. ${ }^{13}$

Biodiesel quality is usually determined based on fuel quality standards, such as the American standards ASTM D $975^{14}$ and D7467 $7^{15}$ and the European standard EN 14214. ${ }^{16}$ The molecular structure of biodiesel renders it highly miscible in the hydrocarbon fractions of crude oil, enabling diesel formulations to be obtained in any proportions for use in diesel cycle engines without the need of cosolvents. ${ }^{16-18}$ When biodiesel is used in diesel cycle engines, its physicochemical properties such as composition, cetane number $(\mathrm{CN})$, viscosity, density, volatility, carbon-hydrogen ratio, lubricity, and biodegradability, ${ }^{19-25}$ as well as the type of engine, injection system, operating conditions, and air-fuel ratio, affect the performance of the thermal cycle and 
air pollutant emissions. ${ }^{24-27}$ A homogeneous mixture in the combustion chamber contributes to reduce emissions of particulate matter (PM), unburned hydrocarbons (HCs) and nitrogen oxides $\left(\mathrm{NO}_{x}\right)$, as well as lower fuel consumption. ${ }^{28,29}$ Although studies have focused on soybean biodiesel produced via the methanol and ethanol routes, the performance and emissions of soybean biodiesel-diesel blends in diesel cycle engines with mechanical injection still require evaluation, since the Brazilian fleet of cars and light commercial vehicles is considered to be an average age of about eight years..$^{30}$ Moreover, studies that use mechanical injection enable relevant parameters to be obtained to evaluate fuels and exhaust emission treatment systems in real operating conditions at low operating costs. The difficulty of complete conversion of the biodiesel obtained by ethylic route and basic catalysis is another factor to be considered. ${ }^{31,32}$

Although Brazil is the largest producer of ethanol obtained from sugar cane, biodiesel is produced exclusively via base catalysis and methylic route mainly due to the difficulty of obtaining high conversion levels using ethanol as reagent. The polar characteristic of the methanol and ethanol make them immiscible in triglycerides at room temperature, and the mixtures are usually mechanically agitated to provide the mass transfer, which produces emulsions during the reaction. These emulsions are, in part, caused by the formation of intermediates as mono and diacylglycerol, which have hydroxyl groups and non-polar hydrocarbon chains. In high concentrations they are strongly reactive surface-active agents, which could prevent mass transfer as expected according to homogeneous reaction kinetics. However, the ethyl esters production given by basic catalysis becomes harder compared to the methyl esters production, due to stable and undesirable emulsion formation during the ethanolysis process. However, in methanolysis, the emulsions are easily separated into two layers, one lower (glycerol) and one higher ester-rich. Instead, in ethanolysis, they are more stable and severe, making it tough to separate and purify the esters. ${ }^{33}$ In this context, this study evaluates the effect of soybean biodiesel produced via base catalysis and via the methanol and ethanol routes (hereinafter referred to as MR and ER, respectively) on the performance and emissions of formulations containing 10 and $20 \%(\mathrm{~m} / \mathrm{m})$ of biodiesel, using base diesel with low sulfur content and $\mathrm{CN}$ of 45 and 50. The soybean biodiesel composition produced via MR and ER was analyzed by gas chromatography with flame ionization detector (GC-FID) and by mass spectrometry. The effect of glyceride presence on soybean biodiesel obtained ER was compared with soybean biodiesel MR when used in formulations for performance tests in a single-cylinder diesel engine with mechanical fuel injection and fixed angle injection, based on parameters such as specific fuel consumption (SFC), emissions of particulate matter and unburned hydrocarbons. The $\mathrm{NO}_{\mathrm{x}}$ emissions were estimated based on data reported in the literature..$^{10,34-37}$

\section{Experimental}

\section{Base fuels and formulations}

The base diesel fuel used was a brand sold in Brazil (S10) with low sulfur content (10 ppm), and CN 50, which was modified with the secondary standard (U17) supplied by Chevron-Phillips to obtain base diesel fuel with CN 45 . Starting from the base fuels $\mathrm{CN} 50$ and $\mathrm{CN} 45$, formulations were prepared containing 10 and $20 \%(\mathrm{~m} / \mathrm{m})$ of soybean biodiesel produced via the methanol route (MR) and the ethanol route (ER) to evaluate their effect on engine performance and emissions. The formulations were dubbed 10MR and 20MR for the methanol route and 10ER and 20ER for the ethanol route.

\section{Analysis of biodiesel composition}

The soybean biodiesel was diluted in dichloromethane for a qualitative analysis of the esters it contained, using a gas chromatograph (Shimadzu model 2010, Kyoto, Japan) coupled to a mass spectrometer with electronimpact ionization detector (Shimadzu, Kyoto, Japan). The chromatographic column was a DB-5 capillary column (methyl silicone with $5 \%$ phenyl groups), $60 \mathrm{~m}$ in length, with $0.25 \mathrm{~mm}$ internal diameter and $0.25 \mu \mathrm{m}$ thick stationary phase. Helium was employed as carrier gas at a flow rate of $1.0 \mathrm{~mL} \mathrm{~min}^{-1}$. Split injection mode of 1:10 was applied. The injector and transfer line were kept at a temperature of $280^{\circ} \mathrm{C}$. The $\mathrm{GC}$ temperature programming was as follows: $4 \mathrm{~min}$ at $40{ }^{\circ} \mathrm{C}, 5{ }^{\circ} \mathrm{C} \mathrm{min}{ }^{-1}$ ramp-up to $190{ }^{\circ} \mathrm{C}$, holding for $4 \mathrm{~min}, 2{ }^{\circ} \mathrm{C} \mathrm{min}{ }^{-1}$ ramp-up to $240{ }^{\circ} \mathrm{C}$, holding for $5 \mathrm{~min}$, and $10{ }^{\circ} \mathrm{C} \mathrm{min}{ }^{-1}$ ramp-up to a final temperature of $280^{\circ} \mathrm{C}$, and holding for $15 \mathrm{~min}$ (analysis time: $87 \mathrm{~min}$ ). The system was operated in the SCAN mode (mass scanning) to produce a mass spectrum of each scanned chromatographic peak, enabling comparisons to be made of the recorded spectra against the spectra in the Mass Spectral Libraries (NIST 14 and Wiley Libraries) $)^{38}$ of the device, and the use of chromatographic patterns obtained under the same conditions as the sample.

For the quantitative analysis of the esters in the biodiesel samples, the most intense ions were selected that could be monitored in the SIM mode (selected ion monitoring) and quantified separately. The analytical conditions were identical to those applied in the above described qualitative process. Each of the esters was analyzed in quintuplicate. 
Analysis of glycerides

Biodiesel samples were diluted in $n$-hexane for the qualitative and quantitative analysis of glycerides, using a Shimadzu GC-17 gas chromatograph (Shimadzu, Kyoto, Japan) coupled to a flame ionization detector (FID). The DB-5 capillary column (methyl silicone with 5\% phenyl groups) was $30 \mathrm{~m}$ long, with $0.25 \mathrm{~mm}$ internal diameter and $0.10 \mu \mathrm{m}$ stationary phase thickness. $\mathrm{N}_{2}$ was used as auxiliary gas and hydrogen as carrier gas, applying an average linear speed of $22.5 \mathrm{~cm} \mathrm{~s}^{-1}$. Injection was performed in splitless mode in $0.5 \mathrm{~min}$, and a 1:10 split ratio was used throughout the analysis, while the temperature of the injector was kept at $350{ }^{\circ} \mathrm{C}$ and that of the detector at $370{ }^{\circ} \mathrm{C}$. The oven temperature was programmed as follows: initial temperature $50{ }^{\circ} \mathrm{C}$, holding for $3 \mathrm{~min}, 7{ }^{\circ} \mathrm{C} \mathrm{min}{ }^{-1}$ ramp-up to $200{ }^{\circ} \mathrm{C}$, holding for $5 \mathrm{~min}, 5^{\circ} \mathrm{C} \mathrm{min}{ }^{-1}$ ramp-up to $297{ }^{\circ} \mathrm{C}$, holding for $2 \mathrm{~min}$, and final $5^{\circ} \mathrm{C} \mathrm{min}{ }^{-1}$ ramp-up to $360{ }^{\circ} \mathrm{C}$, and holding for $15 \mathrm{~min}$ (analysis time: $79 \mathrm{~min}$ ). Glycerides were qualified by comparing the retention times of standards injected under the same chromatographic conditions. The glycerides were quantified by comparison against an external calibration curve.

\section{Engine performance tests}

Engine tests were performed using the base fuels (CN 45 and $\mathrm{CN} 50$ ) and their formulations with 10 and $20 \%$ of soybean biodiesel via MR and ER to determine the specific fuel consumption (SFC) and PM and HC emissions. These tests were performed in a Toyama 7.0 Hp single-cylinder engine, $250 \mathrm{~cm}^{3}$, with mechanical fuel injection, operating at $70 \%$ of maximum power, an injection pressure of 150 bar (fixed injection angle of $-18^{\circ}$ ), a compression ratio of $21: 1,3600 \mathrm{rpm}$ and $10 \% \mathrm{O}_{2}$ in the exhaust gases. The PM in the exhaust gas was quantified gravimetrically by direct filtration of the gas through a glass Microfiber filter (Macherey-Nagel) with $47 \mathrm{~mm}$ diameter. The gas was pumped through the filter element using a vacuum pump, and after cooling, its flow rate was measured using a Sensirion ${ }^{\circledR}$ mass flow meter with a maximum rated capacity of $20 \mathrm{~mL} \mathrm{~min}^{-1}$. The quantification of PM in $\mathrm{mg} \mathrm{m}^{-3}$ was based on the mass of PM retained in the filter divided by the volume of the sampled gas. The average temperature of the filter element was set at $470{ }^{\circ} \mathrm{C}$ to keep the collected PM dry. The condensable volatile hydrocarbons (HCs) present in the diesel engine exhaust gases were collected, along with the water generated in the combustion process, after separating the PM.

The HCs were quantified based on their oxidation in the condensed fraction of the exhaust gases to $\mathrm{CO}_{2}$ in an oxygen atmosphere, using a technique similar to that described by ASTM D6594-11. ${ }^{39}$ The condensed fraction, which was collected using an infusion pump (Samtronics), was transferred to a quartz reactor with a $\gamma$-alumina catalyst bed containing $1.0 \mathrm{wt} . \%$ of $\mathrm{Pt}$ at $700{ }^{\circ} \mathrm{C}$. Carbon dioxide $\left(\mathrm{CO}_{2}\right)$ was quantified in a GC equipped with a thermal conductivity detector (TCD-17A, Shimadzu, Japan), using a packed column (Porapak Q, $8.5 \mathrm{~m} \times 1.6 \mathrm{~mm}$ ) and $\mathrm{H}_{2}$ as the

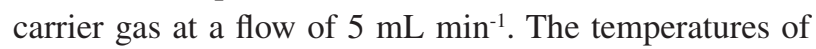
the column oven, injector and detector were 40, 200 and $240{ }^{\circ} \mathrm{C}$, respectively. Quantification was performed using a calibration curve for $\mathrm{CO}_{2}$ generated by injection of an aqueous solution of ethanol $(0.5 \%)$ as the external standard.

\section{Results and Discussion}

Figure 1 illustrates the differential pressure (DP) profiles in the filter element caused by the retention of $\mathrm{PM}$ as a function of sampled gas volume of $\mathrm{CN} 45$ and CN 50 diesel fuels and their respective formulations with 10MR, 20MR, 10ER and 20ER. Lower differential pressure according to the gas volume indicates lower retention of
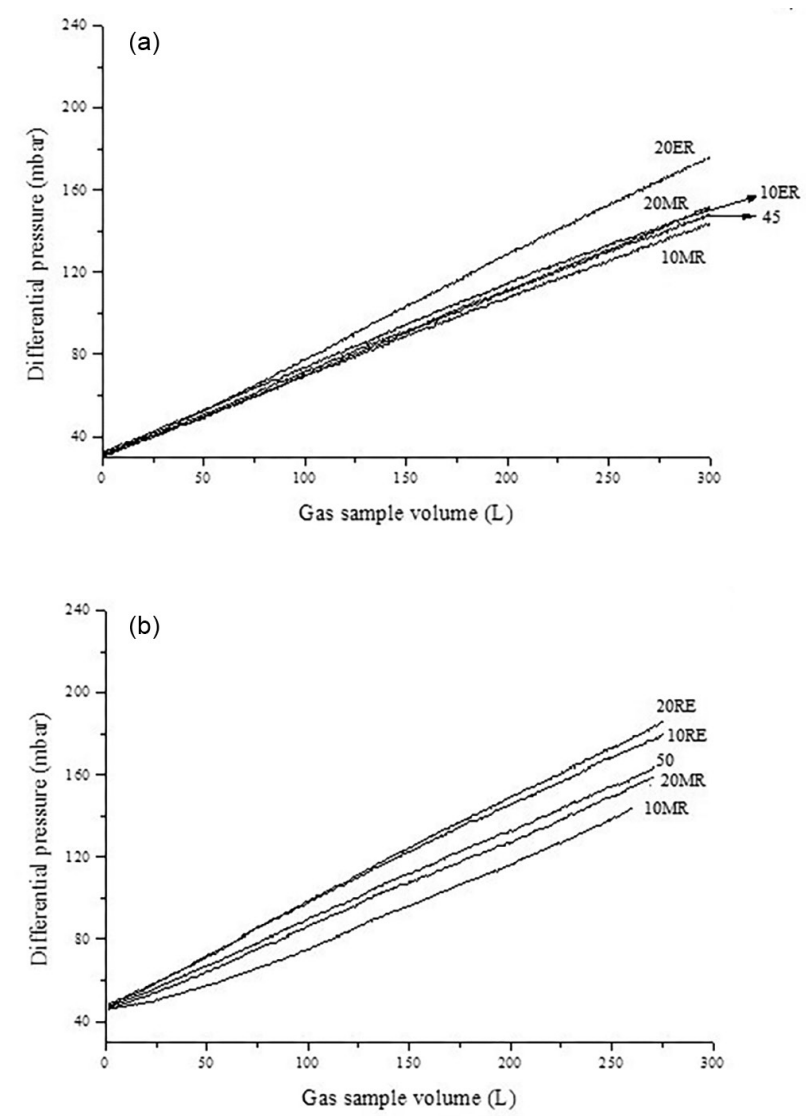

Figure 1. Pressure differential in the filter element resulting from the retention of particulate matter $(\mathrm{PM})$ as a function of the volume of the sampled gas to diesel CN (a) 45 and (b) 50, and their formulations with 10MR, 20MR, 10ER and 20ER. 
PM. Figure 2 depicts the PM emission levels in $\mathrm{mg} \mathrm{m}^{-3}$ for $\mathrm{CN} 45$ and $\mathrm{CN} 50$ diesel fuels and their formulations with 10 and $20 \%$ of MR and ER soybean biodiesel.
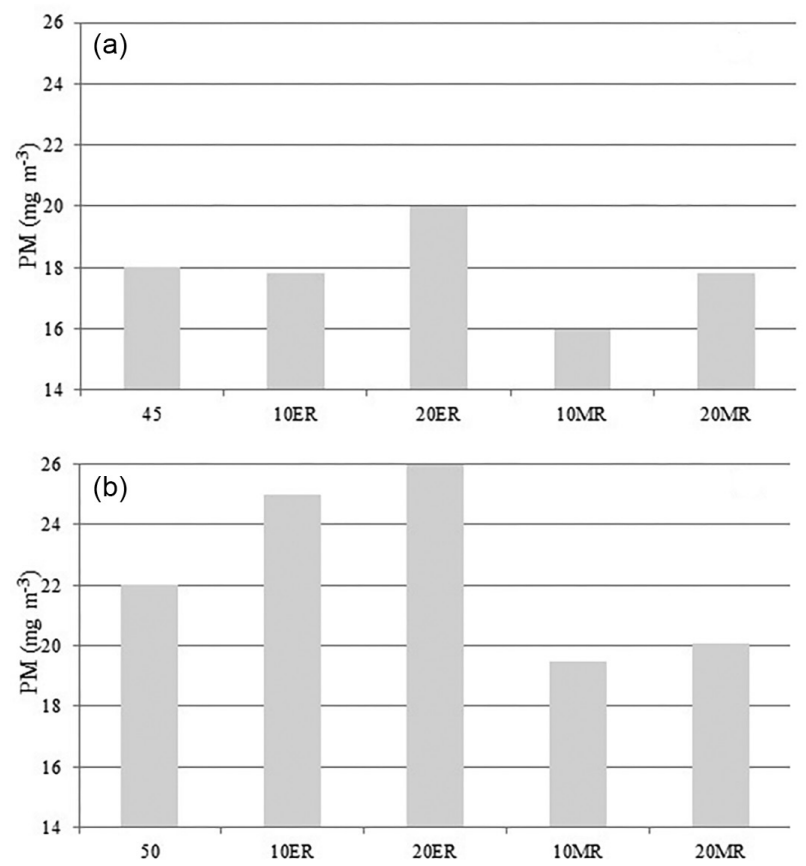

Figure 2. Amount of particulate matter (PM, in $\mathrm{mg} \mathrm{m}^{-3}$ ) for the diesel $\mathrm{CN}$ (a) 45 and (b) 50, and their formulations with 10MR, 20MR, 10ER and 20ER.

A comparison of the differential pressure profiles in the filter element (Figure 1) and the amount of particulate matter measured gravimetrically (see Figure 2) reveals that they show the same tendency, i.e., the formulations with CN 50 present higher differential pressures corresponding to the accumulation of PM. Cataluña and Silva ${ }^{40}$ reported similar results in their discussion of the effect of ignition delay of different diesel formulations in engines with mechanical injection. However, a comparison of the $\mathrm{CN} 45$ and CN 50 fuels formulated with MR and with ER indicates that the former produce lower PM emissions than the latter. PM emissions usually increase with increasing $\mathrm{CN}^{21,40,41}$ and with the size of droplets obtained during the fuel atomization process before combustion. ${ }^{42,43}$

Table 1 describes the main characteristics of the soybean biodiesels produced via MR and ER. As it can be seen, the glycerides parameter for soybean biodiesel produced by the ER indicate the presence of $20 \%(\mathrm{~m} / \mathrm{m})$ of glycerides in the biodiesel, while the biodiesel MR showed no trace of glycerides. The presence of high glyceride concentrations in the end product directly affects the distillation curve by taking the product out of specification. The other parameters are within the values established by international standards.

The presence of glycerides is an important parameter for the characterization of biodiesel samples, not only because it enables the transesterification process to be assessed, but also because glycerides reduce the quality of the end product by increasing PM emissions. This is because unreacted glycerides hinder vaporization due to their higher boiling temperature and because they increase the viscosity of the fuel, thereby reducing combustion efficiency, and may also cause fuel filters to become clogged and deposits formation on engine parts such as pistons, valves and injector nozzles. ${ }^{11,44}$ In this regard, when the formulations evaluated in this study were assessed in a correlated study, they presented different responses.

In vacuum distillation tests performed according to the ASTM D6751-02 standard, ${ }^{45}$ ER biodiesel showed low volatility, since its vaporization was slow. This fuel left behind large amounts of residue, whose upper limit

Table 1. Physical-chemical characteristics of biodiesel from soybean oil via ER and MR

\begin{tabular}{|c|c|c|c|c|}
\hline & ASTM D6751 & EN 14214 & Ethyl route (ER) & Methyl route (MR) \\
\hline Glycerides $/ \% \mathrm{~m} / \mathrm{m}$ & - & - & 20 & $\mathrm{ND}^{\mathrm{a}}$ \\
\hline $\mathrm{AV} /\left(\mathrm{mg} \mathrm{KOH} \mathrm{g}^{-1}\right)$ & $0.50 \max$ & $0.50 \max$ & 0.634 & 0.55 \\
\hline Flash point $/{ }^{\circ} \mathrm{C}$ & $93 \mathrm{~min}$ & $101 \mathrm{~min}$ & 136 & 168 \\
\hline Cold flow: WW / ${ }^{\circ} \mathrm{C}$ & $\mathrm{N} / \mathrm{S}^{\mathrm{b}}$ & $\mathrm{N} / \mathrm{S}$ & -8 & -5 \\
\hline Cetane number & $47.0 \mathrm{~min}$ & $51.0 \mathrm{~min}$ & 51 & 56 \\
\hline $\mathrm{IV} /\left(\mathrm{g} \mathrm{I}_{2}\right.$ per $\left.100 \mathrm{~g}\right)$ & $\mathrm{N} / \mathrm{S}$ & $120 \max$ & 120 & 105 \\
\hline $\mathrm{KV}, 40^{\circ} \mathrm{C} /\left(\mathrm{mm}^{2} \mathrm{~s}^{-1}\right)$ & $1.9-6.0$ & $3.5-5.0$ & 5.83 & 5.71 \\
\hline Sulfur / ppm & $15 \max$ & $10 \max$ & $\mathrm{N} / \mathrm{S}$ & $\mathrm{N} / \mathrm{S}$ \\
\hline Density, $15^{\circ} \mathrm{C} /\left(\mathrm{kg} \mathrm{m}^{-3}\right)$ & $\mathrm{N} / \mathrm{S}$ & $860-900$ & 878 & 881 \\
\hline Specific gravity, $15^{\circ} \mathrm{C}$ & $\mathrm{N} / \mathrm{S}$ & $\mathrm{N} / \mathrm{S}$ & 0.879 & 0.881 \\
\hline Higher heating value / $\left(\mathrm{MJ} \mathrm{kg}^{-1}\right)$ & $\mathrm{N} / \mathrm{S}$ & $\mathrm{N} / \mathrm{S}$ & 41 & 40 \\
\hline
\end{tabular}

${ }^{a} \mathrm{ND}$ : none detected (detection limit: $0.1 \mathrm{ppm}$ ); ${ }^{\mathrm{b}} \mathrm{N} / \mathrm{S}$ : not specified. AV: acid value; WW: weight/weight; IV: iodine value; KV: kinematic viscosity. 
specified by the aforementioned standard is $0.05 \%(\mathrm{~m} / \mathrm{m})$, and which was increased by the presence of glycerides.

From the chromatographic profiles of the MR and ER biodiesels, the composition of the biodiesels produced by the two routes showed similar concentrations of saturated fatty acid esters, since they originate from soybean oil. Biodiesel that is too rich in saturated fatty acids may cause problems in the combustion process. ${ }^{11}$

Some properties of biodiesel, such as CN (ignition quality), enthalpy of combustion, cold flow, oxidative stability, kinematic viscosity, etc., are in large part determined by the composition and molecular structures of their constituent alkyl esters. ${ }^{15,24,25,44,45}$ For example, the melting point, kinematic viscosity and oxidative stability of unsaturated fatty acid methyl esters (FAMEs) increase with the length of the carbon chain and decrease with the increasing number of double bonds. ${ }^{46-48}$ As an indicator of ignition quality, the $\mathrm{CN}$ is one of the most important indicators of quality of diesel fuel for compressionignition engines. The $\mathrm{CN}$ decreases with shorter fatty acid (FA) chains, higher degrees of unsaturation, and branched chain carbons. ${ }^{49} \mathrm{~A}$ lower degree of branching in the molecular structure of fuel can reduce the ignition delay (higher cetane number), and thus, the ignition timing advance. These conditions favor $\mathrm{NO}_{\mathrm{x}}$ formation in the combustion chamber due to the increased residence time of combustion products at high temperatures. Unsaturated fuels change the temperature of the flame front (the higher the degree of unsaturation the higher the adiabatic flame temperature), altering the formation of NO through fast mechanisms, since it is highly influenced by intermediate combustion products. Although it is widely accepted that the concentration of free radicals such as $\mathrm{HO}^{*}$ are determining factors for $\mathrm{NO}_{\mathrm{x}}$ formation, the importance of their effect is secondary to that caused by the increase in temperature. Double bonds have high binding energy, and the large amounts of energy they release contribute to the formation of higher levels of certain free radicals during fuel premixing, resulting in faster NO formation during combustion. ${ }^{50}$

Fuel composition affects the engine's cold start performance, noise levels and exhaust emissions. ${ }^{51}$ Fuels with $\mathrm{CN}$ between 45 and 60 are more suitable for use in diesel engines. ${ }^{52}$ According to Van Gerpen et al..${ }^{53}$ fuels with high CNs will have small ignition delays and small amounts of fuel will be present in the premixed combustion phase because of the short preparation time of the mixture for combustion. The $\mathrm{CN}$ is determined according to a standard test methodology described by the American Society for Testing and Materials (ASTM) ${ }^{54}$ whereby fuels are tested and compared to the ignition delay of standards established in international standards using a single-cylinder engine with electronic injection.

In this study, tests were performed using a single-cylinder engine with mechanical injection, which was monitored with Optrand ${ }^{\otimes}$ pressure sensors in the combustion chamber and in the hose before it meets the injector. The pressure profiles monitored with an oscilloscope indicated that the angle of injection of the fuel was regular. Modifications of the fuel composition using formulations of up to $20 \% \mathrm{~m} / \mathrm{m}$ were found not to cause significant variations in the pressure profiles in the injector hose. Also, modifying the bulk modulus of the fuel did not appear to cause perceptible changes with the use of this type of equipment. The most significant and easily detectable change was in the pressure profile in the combustion chamber. The greater the concentration of fractions with higher boiling points, which is the case of the biodiesel obtained by the ethanol route, the higher the maximum pressure inside the chamber, increasing the formation of $\mathrm{PM}$ and $\mathrm{NO}_{\mathrm{x}}$.

The combustion enthalpy and cetane number of fuels formulated with biodiesel for diesel cycle engines are comparable to those of the fossil fuel, and their sulfur content is low. Because biodiesel has a higher bulk modulus and a higher pressure wave propagation velocity, it causes an advance in fuel injection timing. In engines with electronic injection, this effect is easily circumvented by modifying the injection timing. In engines with mechanical injection, a significant change in the modulus of elasticity alters the fuel injection angle. The higher the pressure wave propagation velocity of the fuel pump, the faster the fuel injector opens, causing an advance in the injection timing. This increases the amount of fuel injected before the upper dead point during the premixing phase, which in turn raises the maximum pressure in the chamber and consequently increases $\mathrm{NO}_{x}$ emissions. $\mathrm{NO}_{\mathrm{x}}$ formation is strictly related to the flame front and combustion chamber temperature. Fuels with a branched molecular structure have a lower boiling point and a greater tendency to cool the surroundings of the fuel droplet, reducing the flame front temperature and thus increasing the ignition delay. Paraffinic fuels exhibit the opposite behavior. In other words, because their enthalpy of vaporization is higher than that of fuels with a branched molecular structure, they have low bulk modulus, low ignition delay, lower fuel injection during premixing, and lower $\mathrm{NO}_{\mathrm{x}}$ emissions. ${ }^{10}$

According to reports in the literature, ${ }^{34-37} \mathrm{NO}_{\mathrm{x}}$ emissions increase in response to increasing flame front and combustion chamber temperatures. Under severe operating conditions with high engine load, the temperature of the flame front and the combustion chamber directly 
affect the combustion process, altering the $\mathrm{NO}_{\mathrm{x}}$ emissions. Unsaturated fatty acids (methyl linoleate, C18:2; > 50\%) predominated, which favors the oxidative process, according to the literature. ${ }^{34}$ However, to date there are no data that demonstrate the influence of fatty acids on PM emissions. On the other hand, an analysis of the iodine value (IV) indicated that the IV of the ER biodiesel additive was higher. The IV indicates the fuel unsaturation content and hence the tendency of the fuel to oxidize, which favors the occurrence of polymerization and formation of gum deposits in diesel cycle engines. ${ }^{51,55-57}$

Figure 3 presents the values of $\mathrm{HC}$ emissions (in the form of $\mathrm{CH}_{4}$ ) in $\% \mathrm{~m} / \mathrm{m}$ of the base fuels and their respective formulations with MR and ER soybean biodiesel. It should be noted that diesel fuel with $\mathrm{CN} 50$ produces lower HC emissions than diesel with $\mathrm{CN} 45$. However, $\mathrm{HC}$ emissions gradually increased in response to increasing proportions of both ER and MR biodiesel. On the other hand, the amount of $\mathrm{HC}$ in diesel CN 45 and in its formulations with ER biodiesel was practically the same, and decreased in its formulations with MR, indicating better combustion quality.
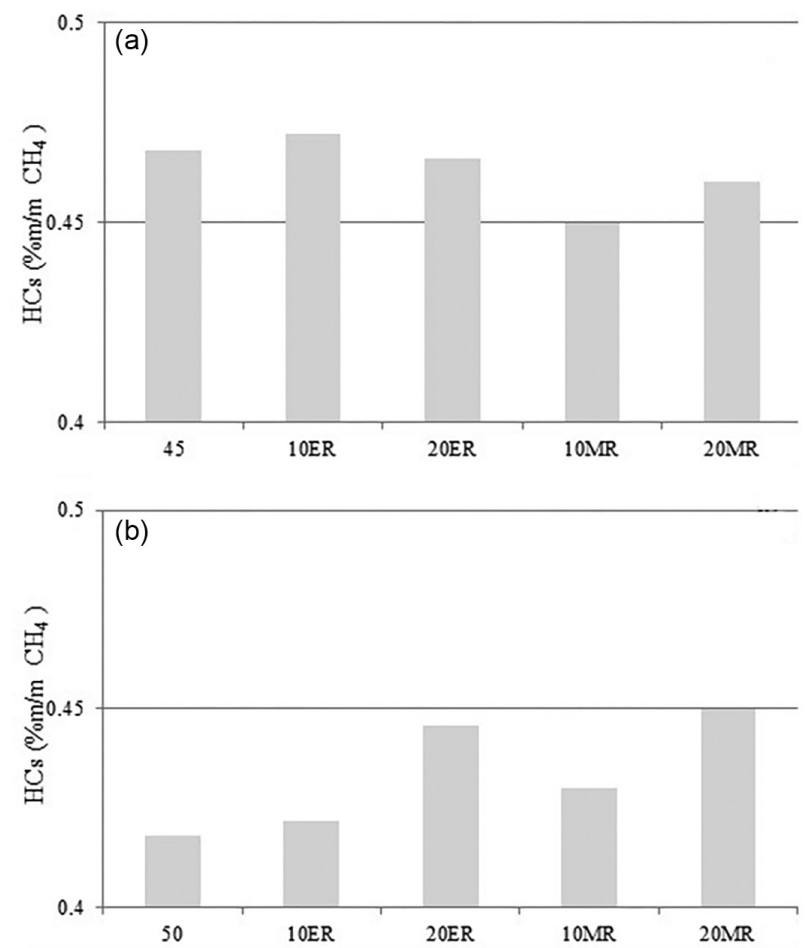

Figure 3. Concentration of $\mathrm{HCs}\left(\% \mathrm{~m} / \mathrm{m} \mathrm{CH}_{4}\right)$, in diesel $\mathrm{CN}$ : (a) 45 and (b) 50, and their formulations with 10MR, 20MR, 10ER and 20ER.

The higher HC emissions of the formulations of diesel CN 50 with biodiesel can be attributed to physicochemical properties such as viscosity, surface tension and volatility. These properties lead to increased fuel droplet size and extinguish the flame in the cold areas of the combustion chamber adjacent to the cylinder walls, favoring the condensation of unreacted hydrocarbon radicals on their surfaces. The kinematic viscosity $\left(40{ }^{\circ} \mathrm{C}\right)$ specified for diesel $\mathrm{S} 10$, herein referred to as $\mathrm{CN} 50$ and $\mathrm{CN} 45$, should range from 2.0 to $4.5 \mathrm{~mm}^{2} \mathrm{~s}^{-1},{ }^{58}$ but since the ER and MR biodiesels showed values of 5.83 and $5.71 \mathrm{~mm}^{2} \mathrm{~s}^{-1}$, respectively (Table 1), the kinematic viscosity was expected to be higher in their formulations with the base diesel.

Figure 4 illustrates the results of specific fuel consumption (SFC), in $\mathrm{g} \mathrm{kW}^{-1} \mathrm{~h}^{-1}$, as a function of test time for $\mathrm{CN} 45$ and 50 fuels and their respective formulations with 10MR, 20MR, 10ER and 20ER. Engine fuel consumption with the formulations is higher than with the base diesel (CN 45 and 50), particularly when the biodiesel content in the mixture is increased. The $\mathrm{CN}$ is
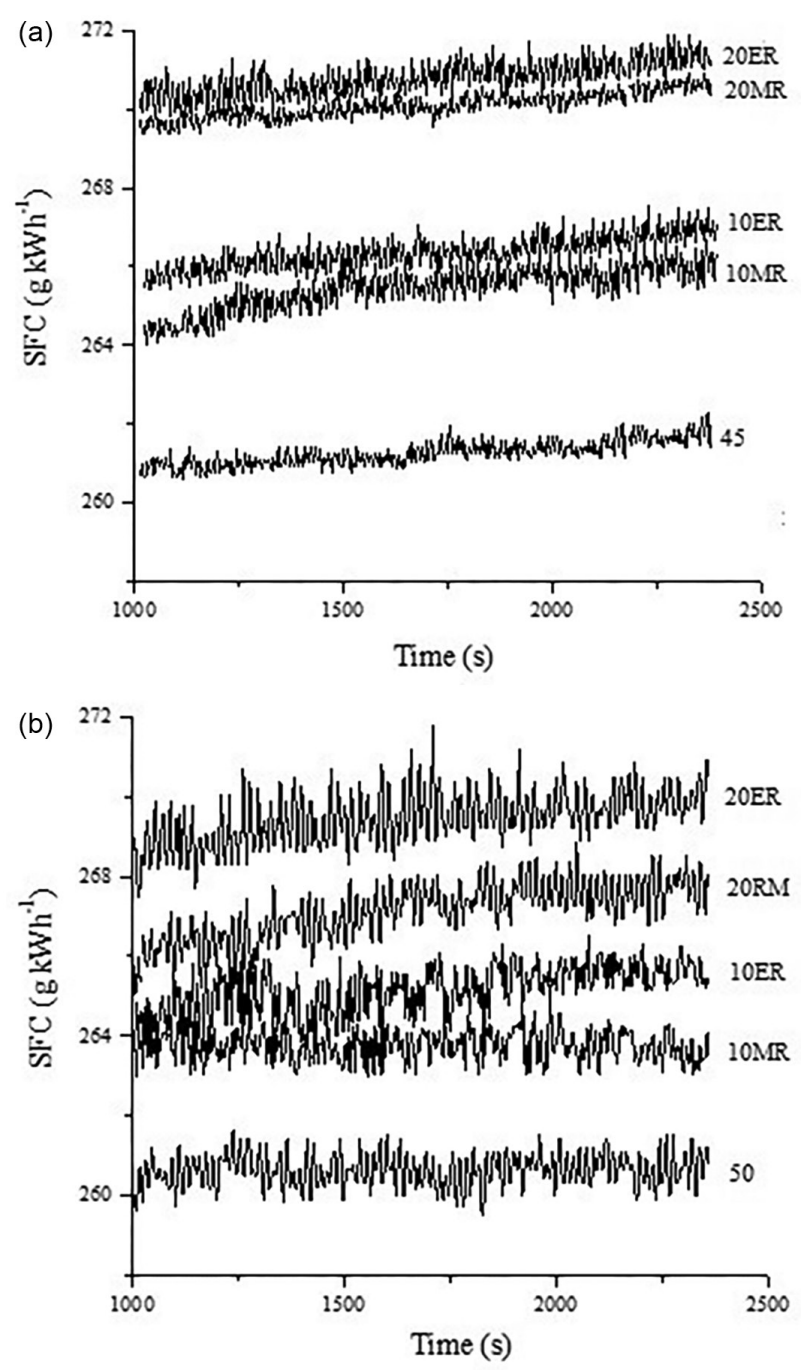

Figure 4. Specific consumption $\left(\mathrm{g} \mathrm{kW}^{-1} \mathrm{~h}^{-1}\right)$ as a function of time in diesel CN: (a) 45 and (b) 50, and their formulations with 10MR, 20MR, 10ER and 20ER. 
one of the determining factors of SFC in diesel engines with a constant injection angle, which is the case of engines with mechanical fuel injection. ${ }^{34,59}$ The increase in consumption of the formulations of $20 \% \mathrm{ER}$ and MR with diesel CN 45 showed a linear relationship with the heat of combustion. The base fuels (CN 45 and 50) show higher combustion enthalpy (45 $\mathrm{MJ} \mathrm{kg}^{-1}$ ) than the biodiesels ER (41 $\left.\mathrm{MJ} \mathrm{kg}^{-1}\right)$ and MR (40 $\left.\mathrm{MJ} \mathrm{kg}^{-1}\right)$; hence, it is expected that any increase in the concentration of these biodiesels will lead to a proportional increase in consumption. Increasing the percentage of biodiesel in the formulation may slow down its atomization in the system, making combustion difficult and reducing its efficiency. In the case of formulations with ER, one of the probable causes of the increase in fuel consumption can be attributed to the decrease in combustion enthalpy due to the presence of $20 \%$ of glycerides in its composition.

\section{Conclusions}

This study assessed the combustion properties, such as $\mathrm{PM}$ and $\mathrm{HC}$ emissions, DP and SFC, using a single-cylinder diesel engine with mechanical fuel injection. The $\mathrm{CN}$ was found to have an influence on PM and HC emissions with this type of engine. The formulations with diesel CN 50 showed higher values of DP, indicating higher PM emissions. On the other hand, $\mathrm{HC}$ emissions with this formulation were lower than with the formulation with diesel CN 45. This study also showed that increasing the MR and ER content in the formulations increased their SFC when compared to that of the base diesels, a fact that was attributed mainly to the reduction of the combustion enthalpy of the mixture in response to the addition of the biodiesels. It was also found that the SFC of the $\mathrm{CN} 45$ diesel formulated with ER was higher than that formulated with MR, indicating that the presence of $20 \%$ of glycerides in its composition and its lower $\mathrm{CN}$ exerted a more marked influence on the SFC. Based on the results of this study, both PM and SFC increase in response to increasing ER. In addition, biodiesel formulations containing up to $10 \% \mathrm{MR}$ for diesel engines with mechanical injection also showed lower pollutant emissions.

The restriction on ER biodiesel industrial production process is mainly due to the difficulty to reach high conversion levels, resulting in a product out of specification according to the international quality standards. Although the ER biodiesel additive offers environmental advantages in production, its quality in terms of the production of particulate matter is lower than that of the MR biodiesel additive.

\section{References}

1. Guldhe, A.; Singh, B.; Mutanda, T.; Permaul, K.; Bux, F.; Renewable Sustainable Energy Rev. 2015, 41, 1447.

2. Menegazzo, M. L.; Lucas, B. F.; Alcade, L. B.; Petenucci, M. E.; Fonseca, G. G.; J. Environ. Chem. Eng. 2015, 3, 150.

3. Singh, B.; Guldhe, A.; Rawat, I.; Bux, F.; Renewable Sustainable Energy Rev. 2014, 29, 216.

4. Kucek, K. T.; Cesar-Oliveira, M. A. F.; Wilhelm, H. M.; Ramos, L. P.; J. Am. Oil Chem. Soc. 2007, 84, 385.

5. Pinto, A. C.; Guarieiro, L. L. N.; Rezende, M. J. C.; Ribeiro, N. M.; Torres, E. A.; Lopes, W. A.; Pereira, P. A. P.; de Andrade, J. B.; J. Braz. Chem. Soc. 2005, 16, 1313.

6. Mazivila, S. J.; Mitsutake, H.; de Santana, F. B.; Gontijo, L. C.; Santos, D. Q.; Borges Neto, W.; J. Braz. Chem. Soc. 2015, 26, 642.

7. da Silva, W. L. G.; de Souza, P. T.; Shimamoto, G. G.; Tubino, M.; J. Braz. Chem. Soc. 2015, 26, 1745.

8. Verma, P.; Sharma, M. P.; Renewable Sustainable Energy Rev. 2016, 62, 1063.

9. Nabi, N.; Shahadat, M. Z.; Rahman, S.; Beg, R. A.; SAE Tech. Pap. 2004, 01, 3034.

10. Wang, Y.; Liu, H.; Lee, C.-F. F.; Renewable Sustainable Energy Rev. 2016, 64, 569.

11. Kegl, B.; Energy Fuels 2016, 20, 1460.

12. Barnwal, B. K.; Sharma, M. P.; Renewable Sustainable Energy Rev. 2005, 9, 363.

13. Filoso, S.; Carmo, J. B.; Mardegan, S. F.; Lins, S. R M.; Gomes, T. F.; Martinelli, L. A.; Renewable Sustainable Energy Rev. 2015, 52, 1847.

14. American Society for Testing and Materials (ASTM) D975-16a; Standard Specification for Biodiesel Fuel Oils; ASTM International: West Conshohocken, PA, 2016.

15. American Society for Testing and Materials (ASTM) D7467-17; Standard Specification for Biodiesel Fuel Oil, Biodiesel Blend (B6 and B20); ASTM International: West Conshohocken, PA, 2017.

16. EN 14214: Automotive Fuels - Fatty Acid Methyl Esters (FAME) for Diesel Engines - Requirements and Test Methods; European Committee for Standardization, Berlin, 2008. Available at http:// agrifuelsqcs-i.com/attachments/1598/en14214.pdf, accessed in May 2017.

17. Pimentel, M. F.; Ribeiro, M. G. S.; Cruz, R. S.; Stragevitch, L.; Pacheco, J. G.; Teixeira, L. S. G.; Microchem. J. 2006, 82, 201.

18. Srivastava, A.; Prassad, R.; Renewable Sustainable Energy Rev. 2000, 4, 111.

19. Knothe, G.; Fuel Process. Technol. 2005, 86, 1059.

20. Atadashi, I. M.; Aroua, M. K.; Aziz, A.; Renewable Sustainable Energy Rev. 2010, 14, 1999.

21. Guibet, J. C.; Faurace-Birchem, E.; Fuels and Engines; Editions Technip: Paris, 1999. 
22. Mudge, S. M.; Pereira, G.; Spill Sci. Technol. Bull. 1999, 5, 353.

23. Pinzi, S.; Rounce, P.; Herreros, J. M.; Tsolakis, A.; Dorado, M. P.; Fuel 2014, 104, 170.

24. Knothe, G.; Energy Fuels 2008, 22, 1358.

25. Ramos, M. J.; Fernández, C. M.; Casas, A.; Rodríguez, L.; Pérez, Á.; Bioresour. Technol. 2009, 100, 261.

26. Makareviciene, V.; Janulis, P.; Renewable Energy 2003, 28, 2395.

27. Paulo, A. A.; Costa, R. S.; Rahde, S. B.; Vecchia, F. D.; Seferin, M.; Santos, C. A.; Appl. Therm. Eng. 2016, 98, 288.

28. Park, S. H.; Kim, H. J.; Suh, H. K.; Lee, C. S.; Int. J. Heat Fluid Flow 2009, 30, 960.

29. He, C.; Ge, Y.; Tan, J.; Han, X.; Int. J. Energy Res. 2008, 32, 1329.

30. Confederação Nacional da Indústria (CNI); Associação Nacional dos Fabricantes de Veículos Automotores; Indústria Automobilística e Sustentabilidade; CNI: Brasília, 2012. Available at https://static-cms-si.s3.amazonaws.com/media/ filer_public/a3/27/a3276293-13eb-4210-9316-696ff6d94950/ $20131002175420378115 i . p d f$, accessed in May 2017.

31. Altamirano, C. A. A.; Yokoyama, L.; Medeiros, J. L.; Araújo, O. Q. F.; Appl. Energy 2016, 184, 1246.

32. Dermibas, A.; Energy Convers. Manage. 2008, 49, 125.

33. Refaat, A. A.; Int. J. Environ. Sci. Technol. 2010, 7, 183.

34. Knothe, G.; Matheaus, A. C.; Ryan, T. W.; Fuel 2003, 82, 971.

35. Ruina, L.; Zhong, W.; Peiyong, N.; Yang, Z.; Mingdi, L.; Lilin, L.; Fuel 2014, 128, 180.

36. Lapuerta, M.; Armas, O.; Rodriguez-Fernández, J.; SAE Int. J. Fuels Lubr. 2009, 1, 1150.

37. Puhan, S.; Saravanan, N.; Nagarajan, G.; Vedaraman, N.; Biomass Bioenergy 2010, 34, 1079.

38. http://www.sisweb.com/software/ms/wiley.htm, accessed in June 2017.

39. American Society for Testing and Materials (ASTM) D659111; Standard Test Method for Determination of Aromatic Hydrocarbon Types in Middle Distillates-High Performance Liquid Chromatography Method with Refractive Index Detection; ASTM International: West Conshohocken, PA, 2011.

40. Cataluña, R.; Silva, R.; J. Combust. 2012, 1.

41. Owen, K.; Coley, T.; Automotive Fuels Reference Book; Society of Automotive Engineers Inc.: Warrendale, USA, 1995.

42. Elkobt, M. M.; Prog. Energy Combust. Sci. 1982, 8, 61.
43. Kim, H. J.; Park, S. H.; Lee, C. S.; Fuel Process. Technol. 2010 , 91, 354.

44. Bowman, M.; Hilligoss, D.; Rasmussen, S.; Hydrocarbon Process. 2006, 103.

45. American Society for Testing and Materials (ASTM) D6751-02; Standard Specification for Biodiesel Fuel (B100) Blend Stock for Distillate Fuels; ASTM International: West Conshohocken, PA, 2002.

46. Demirbas, A.; Fuel 2008, 87, 1743.

47. Knothe, G.; Energy Environ. Sci. 2009, 2, 759.

48. Knothe, G.; Dunn, R. O.; J. Am. Oil Chem. Soc. 2009, 86, 843.

49. Knothe, G.; Steidley, K. R.; Fuel 2005, 84, 1059.

50. Moser, B. R.; J. Am. Oil Chem. Soc. 2009, 86, 699.

51. Knothe, G.; J. Am. Oil. Chem. Soc. 2002, 9, 847.

52. Knothe, G.; Gerpen, J. V.; Krahl, J.; The Biodiesel Handbook, $2^{\text {nd }}$ ed.; Elsevier: Champaign, 2010.

53. Van Gerpen, J.; Shanks, B.; Pruszko, R.; Clements, D.; Knothe, G.; Biodiesel Analytical Methods: August 2002-January 2004, NREL/SR-510-36240; National Renewable Energy Laboratory (NREL): Golden, Colorado, USA, 2004.

54. American Society for Testing and Materials (ASTM) D 613-05; Standard Test Method for Cetane Number of Diesel Fuel Oil; ASTM International: West Conshohocken, PA, 2005.

55. Bunjumea, P.; Agudelo, J. R.; Agudelo, A. F.; Energy Fuels 2011, 25, 77.

56. Lang, X.; Dalai, A. K.; Bakhshi, N. N.; Reaney, M. J.; Hertz, P. B.; Bioresour. Technol. 2001, 80, 53.

57. Wagner, H.; Luther, R.; Mang, T.; Appl. Catal., A 2001, 221, 429.

58. Agência Nacional do Petróleo, Gás Natural e Biocombustíveis (ANP), Resolução ANP No. 50, de 23/12/2013, Diário Oficial da União (DOU) 24/12/2013. Available at http://pesquisa.in.gov. br/imprensa/jsp/visualiza/index.jsp?data=24/12/2013\&jornal= 1\&pagina=104, accessed in May 2017.

59. Caetano, N. R.; Cataluña, R.; Vielmo, H. A.; Int. Rev. Mech. Eng. 2015, 9, 124.

Submitted: January 12, 2017

Published online: June 5, 2017

FAPERGS/CAPES has sponsored the publication of this article. 